\title{
Article \\ Built Environment and Physical Activity among Adults in Hong Kong: Role of Public Leisure Facilities and Street Centrality
}

\author{
Ting Zhang ${ }^{1,2}$, Bo Huang ${ }^{2,3,4, *(\mathbb{D})}$, Hung Wong ${ }^{5,6} \mathbb{D}^{\text {, }}$, Samuel Yeung-Shan Wong ${ }^{6,7} \mathbb{D}$ \\ and Roger Yat-Nork Chung ${ }^{6,7}$ (D)
}

1 School of International and Public Affairs, Shanghai Jiao Tong University, Shanghai 200030, China; tingzhang@sjtu.edu.cn

2 Institute of Space and Earth Information Science, The Chinese University of Hong Kong, Hong Kong 999077, China

3 Department of Geography and Resource Management, The Chinese University of Hong Kong, Hong Kong 999077, China

4 Shenzhen Research Institute, The Chinese University of Hong Kong, Shenzhen 518057, China

5 Department of Social Work, The Chinese University of Hong Kong, Hong Kong 999077, China; hwong@cuhk.edu.hk

6 Institute of CUHK Institute of Health Equity, The Chinese University of Hong Kong, Hong Kong 999077, China; yeungshanwong@cuhk.edu.hk (S.Y.-S.W.); rychung@cuhk.edu.hk (R.Y.-N.C.)

7 JC School of Public Health and Primary Care, The Chinese University of Hong Kong, Hong Kong 999077, China

* Correspondence: bohuang@cuhk.edu.hk; Tel.: +852-39436536

check for updates

Citation: Zhang, T.; Huang, B.;

Wong, H.; Wong, S.Y.-S.;

Chung, R.Y.-N. Built Environment and Physical Activity among Adults in Hong Kong: Role of Public Leisure Facilities and Street Centrality. Land 2022, 11, 243. https://doi.org/ 10.3390/land11020243

Academic Editor: Thomas

Panagopoulos

Received: 21 December 2021

Accepted: 1 February 2022

Published: 6 February 2022

Publisher's Note: MDPI stays neutral with regard to jurisdictional claims in published maps and institutional affiliations.

Copyright: () 2022 by the authors Licensee MDPI, Basel, Switzerland. This article is an open access article distributed under the terms and conditions of the Creative Commons Attribution (CC BY) license (https:// creativecommons.org/licenses/by/ $4.0 /)$.

\begin{abstract}
Physical inactivity has been identified as the fourth leading risk factor for global mortality, and has been shown to be related to the built environment. To fill the literature gap from a non-Western setting, we examined: (1) the associations between the built environment and physical activity (PA) behaviors, (2) how the association of street centrality with PA is mediated by public leisure facilities, and (3) whether the association of the built environment with PA differs among people with different perceived PA barriers in Hong Kong. Cross-sectional survey data on 1977 adults were used. Exposure to the built environment was assessed in terms of the density of four types of public leisure facilities (gyms, parks, recreational facilities, and sports facilities) and street centrality. Street centrality was a composite index calculated by gathering four related indicators (reach, betweenness, straightness, and intersection density). Covariates, including socio-demographic variables, perceived neighborhood environment, and perceived PA barriers, were considered. Gym density was significantly associated with vigorous physical activity, but the association became non-significant after controlling for covariates. Sports facility density was associated with a greater probability of moderate physical activity (MPA) and was greater in those who had perceived PA barriers. Additionally, sports facilities partially mediated the association of street centrality with MPA, and fully mediated the association of street centrality with prolonged sitting. Higher park density was associated with lower odds of prolonged sitting. It is important for governments to provide more sports facilities and parks to promote active PA, and to reduce sitting time in adults by creating an active built environment.
\end{abstract}

Keywords: physical activity; sitting time; street centrality; perceived neighborhood environment; perceived barrier

\section{Introduction}

Physical inactivity has been identified as the fourth leading risk factor for global mortality by the World Health Organization (WHO), and is one of the major risk factors for non-communicable diseases (NCDs) [1]. In Hong Kong, most people have a sedentary lifestyle, and an increasing disease burden from NCDs is evident [2]. Therefore, there is an urgent need to better understand the associations between environmental features 
and behaviors in order to enable the design of an environment conducive to participation in physical activity (PA). In a systematic review of the associations of built environment infrastructural changes (BEICs) with PA, active transportation, and sedentary behavior, it was found that the effectiveness of BEICs varies greatly with the types of outcome measured [3]. In another comprehensive review, it was determined that greenery, public leisure space (e.g., roof gardens, fitness clubs, public spaces), the specific designs of roads, trails and paths, safety and security provisions, and a wider choice of facilities (e.g., sidewalks, cycling paths, treadmills, stairs) can encourage walking and cycling activities [4]. An international cross-sectional study of 14 cities worldwide showed that four of six environmental attributes were significantly and positively related to PA, namely, net resident density, intersection density, public transport density, and park density [5]. Moreover, safe, walkable, and aesthetically pleasing neighborhoods, with access to overall and specific destinations and services, positively influenced older adults' PA participation [6].

Although there is an increasing amount of research on the relationship between the built environment and PA, most studies were conducted in non-Asian areas. In addition, the evidence from Western countries cannot be simply generalized to Hong Kong, which has very different built environment attributes. For example, Hong Kong has a land mass of $1081.95 \mathrm{~km}^{2}$ and its population in 2019 was estimated to be 7.506 million, which equates to a population density of 6940 people per $\mathrm{km}^{2}$ [7]. Since Hong Kong is one of the most densely populated areas in the world and, taken together with its highly developed transportation network and densely occupied buildings, evidence-based research with context-specific environmental variables are needed to examine whether the built environment has a significant impact on Hong Kong citizen's PA. A few studies conducted in Hong Kong in this research area have focused on the built environment-walking relationship and on the older persons ( $>65$ years), with little examination of specific PA outcomes derived from the use of specific types of facilities [8-10].

Street layout, such as intersection density, street integration, and centrality, is another element of the built environment that is related to PA. It has been found that local destinations partially mediate the association of street centrality with travel behaviors [11,12]. However, we could not find any study that focused on the mediating role of public leisure facilities on the association between street centrality and PA. In addition, the issue of attitude-induced self-selection, which refers to the tendency of people to choose locations based on their behavior-related attitudes, has always been a challenge in environmentbehavior studies [13]. This may lead to difficulties when we want to identify the causal effects of the environment, e.g., reverse causation and confounding. Both external and internal perceived barriers could also significantly affect people's likelihood to engage in PA. Therefore, the interaction associations between objective environment variables and perceived barriers to engaging in PA needs to be investigated.

To simultaneously investigate the abovementioned dimensions, we analyzed crosssectional data from 1977 adults in Hong Kong to address three aspects: (1) the independent association of specific types of public leisure facilities (gyms, parks, and recreation and sports facilities) and street centrality with three PA behaviors; (2) the mediating associations of each type of public leisure facilities on the relationship between street centrality and PA; and (3) whether the associations of built environmental variables with PA differs in people who perceive different barriers to engaging in PA.

\section{Theoretical Foundation and Hypothesis Development}

This study proposed three hypotheses with respect to the abovementioned three aspects. First, public leisure facilities and street centrality are significant predictors of PA. Second, public leisure facilities mediate the association between street centrality and PA (Figure 1). Third, the associations between environmental variables and PA are significantly different for people who perceive different PA barriers. The first and third hypothesis could be derived from the literature reviewed [4-6], and are consistent with the classical Bronfenbrenner's socio-ecological model, which takes multiple influences into considera- 
tion on a specific health behavior, as well as the interaction of personal and environmental factors [14].

(1)

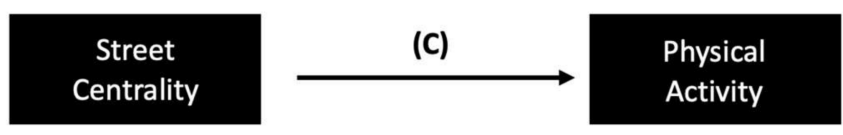

(2)

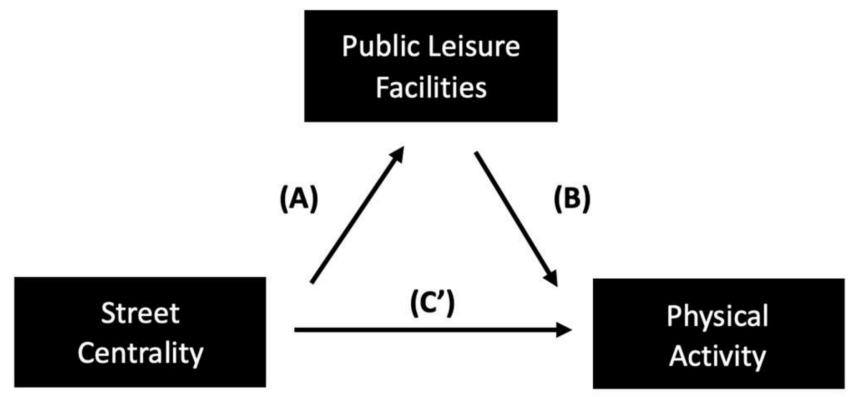

Figure 1. Models of the hypothesized relationships among street centrality, public leisure facilities, and adults' PA.

This section mainly explores the theoretical foundation and the logical inference of the second hypothesis (Figure 1 , street centrality $\rightarrow$ public leisure facilities $\rightarrow$ PA). The literature review has revealed that street layout and facility factors are generally associated with PA; however, the mechanism among them was unclear in previous studies. Does the street centrality affect PA directly or indirectly through public leisure facilities? Hillier's Theory of Natural Movement points out that street centrality (the configuration of the urban grid) itself is the main generator of pedestrian movement, which emphasizes the importance of urban form [15]. Meanwhile, this theory admitted the potential moderating role of attractors (accessibility of destination) by stating that land uses located to take advantage of passing trade act as multipliers on the basic pattern of 'natural movement' generated by street centrality, which extends the Attraction Theory [15].

Logically, the long-existing street configuration cannot be affected by short-term variables, such as the presence of facilities, but the reverse causality is possible. Street centrality is a vital aspect of urban centrality, which incorporates location accessibility at a more precise street level [16]. The relationship between urban location and land use patterns is a classic theoretical issue in economic geography. Based on Location Theory, street centrality affects the location choice of land use or facilities, corresponding with the Law of Minimum Effect or the Principle of Least Effort [17]. Alonso's Bid Rent Model, setting Ricardo's residual value theory of land into an explicitly spatial context, has an abiding appeal as a powerful abstraction for understanding the spatial structure of land uses and their relations with the urban center. Many empirical studies have revealed the association of street centrality with population density [18], employment density [19], building density [20], the location of economic activities [21-23], and land use allocations [24-29]. This kind of research concentrates on commercial land use, and the logic behind it is that the more central the land, the more expensive the land; therefore, the land use density is higher near the urban center to balance the profit.

A few studies have shown the association between street centrality and leisure facilities in Chinese metropolises [30-33]. However, it remains an open question whether the marketoriented neoliberal model could still explain the spatial logic of public land uses or public facilities, such as public leisure facilities, which are intervened in by the government. Understanding the planning logic of public facilities by government helps us solve the mystery. Along with new urbanism and smart growth, transit-oriented development (TOD) 
has been one of the critical planning strategies for developing dense urban forms, especially in dense metropolises, underlining the connections between metro stations, living areas, services, recreational activities, and workplaces. Hong Kong, with an average population of 6940 people $/ \mathrm{km}^{2}$, has one of the world's densest urban environments. The Hong Kong government adopts a TOD approach for its long-term urban planning, connecting residents' everyday lives within TOD areas through the development of a "rail + property" mode. The Hong Kong Planning Standards and Guidelines for recreation, open space, and greening stipulate that the availability of open spaces should be based on the provision for each person, and that of recreation facilities should be based on a range of population thresholds. Generally speaking, the location and provision of public leisure facilities in Hong Kong are based on the fixed service population density (relating to residential building density) and the floating population density. On the one hand, public service land use follows housing density. Because of the liberalization of the housing market and the TOD approach for public housing, the density of public facilities also follows the logic of Location Theory. On the other hand, the Theory of Natural Movement points out that street centrality predicts human flow. The expectedly high floating population density is also the reason for the high density of public leisure facilities, which is intended to maximize the efficiency of public service. In addition to the above inference from these theories, two empirical studies in Hong Kong also depicted significantly positive relationships between community facility distribution and urban centrality and building density [34,35].

Relying on the theoretical and empirical evidence found in the literature, when there is a mediating association, the relationship between street centrality and PA can be partially explained by public leisure facilities. Therefore, we proposed the second hypothesis (Figure 1), which not only aims to verify the association among street centrality, facilities factors, and PA, but also highlights the importance of public leisure facilities in promoting PA.

\section{Materials and Methods}

\subsection{Study Design}

Figure 2 provides a schematic representation of the research workflow. This study was conducted in Hong Kong, a Special Administrative Region of China. An individual-level cross-sectional dataset was combined with relevant latitude and longitude data to explore the associations between the built environment features and PA behaviors. Objective data and geographic information system (GIS) data were used to characterize the microlevel environmental conditions of each respondent. To characterize the PA-related built environment, we examined the density of four types of public leisure facilities (gyms, parks, recreational facilities, and sports facilities) and street centrality. Street centrality was a composite index, calculated by gathering four related indicators (reach, betweenness, straightness, and intersection density). The first three indicators (reach, betweenness, and straightness) were calculated using Urban Network Analysis [36]. Reach describes the number of other nodes in a graph that are reachable at a shortest path distance. Betweenness estimates the number of times the focused node lies on the shortest paths between pairs of other reachable nodes in a graph that lie within the network radius. Straightness illustrates how close the shortest network distances between the focused node and other nodes are.

Measures of environmental exposure to neighborhood public leisure facilities and street centrality were determined by an analysis within a defined Euclidean distance (straight-line distance) from the respondents' home. 


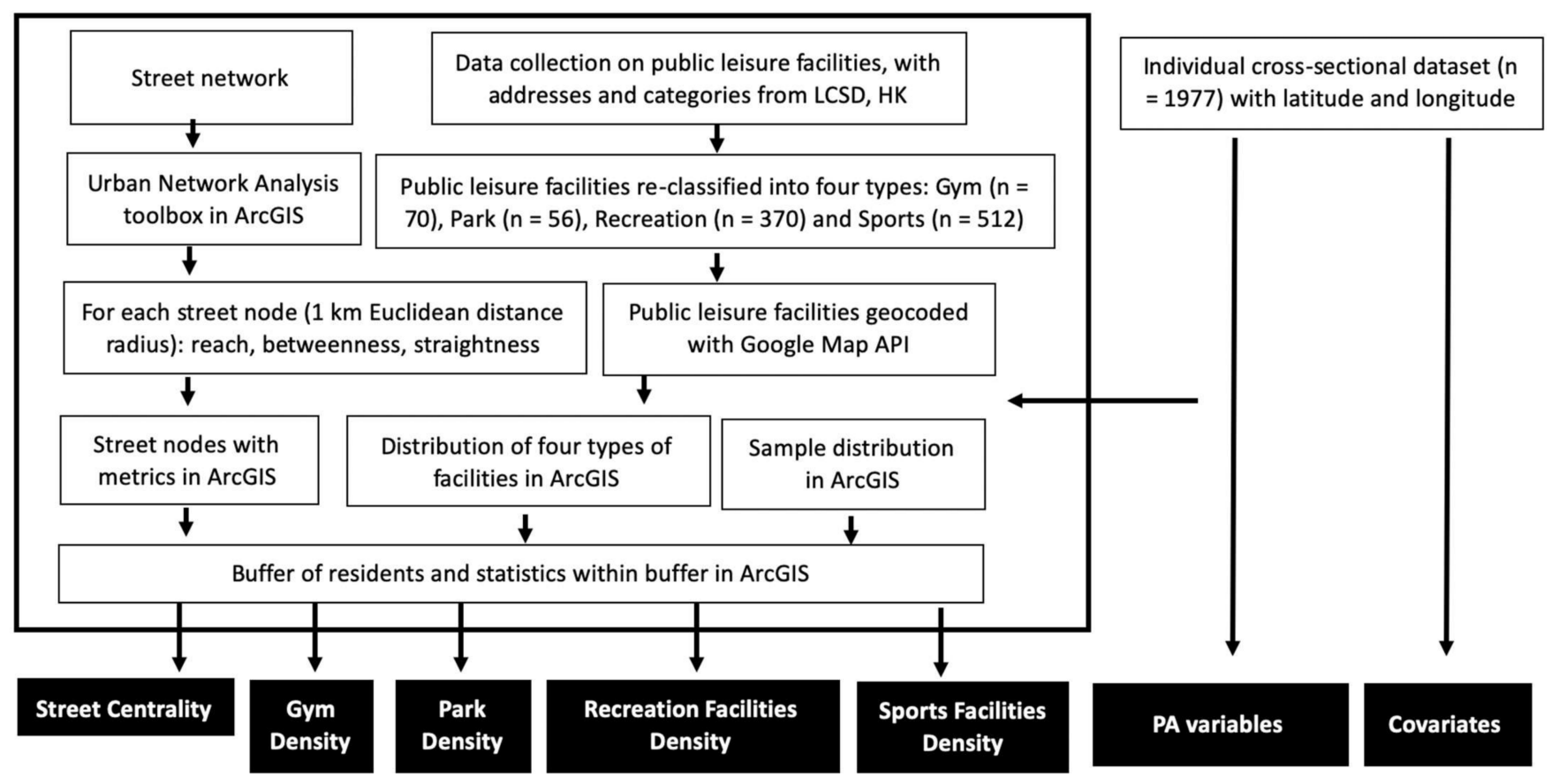

Statistical analysis - a series of logistic regression models examining:

(1) Independent associations of specific types of public leisure facilities (gyms, parks, recreation facilities and sports facilities) and street centrality with VPA, MPA and prolonged sitting.

(2) Mediation analyses by public leisure facilities for the associations between street centrality and PA behaviors.

(3) Determination of whether the effects of the built environmental variables (public facilities and street centrality) on PA differ in people who perceive different barriers to PA

Figure 2. Research workflow. PA: Physical Activity; VPA: Vigorous Physical Activity; MPA: Moderate Physical Activity; LCSD: The Leisure and Cultural Service Department.

\subsection{Survey Data and Variables}

Data from a representative sample of 1977 Hong Kong adults were used, derived from the first wave of the Strategic Public Policy Research (SPPR) project called "Trends and Implications of Poverty and Social Disadvantages in Hong Kong: A Multi-disciplinary and Longitudinal Study" $[37,38]$. This sample has detailed information on the latitude and longitude of the respondents' homes, and the cross-sectional survey data were acquired via face-to-face interviews conducted between May 2014 and July 2015. In this study, the following variables were collected: sociodemographic variables (age, sex, marital status, house type, self-reported poverty level, monthly income (equivalized household income; this study uses an equivalence scale, which divides household income by the square root of household size) [36], educational attainment, birthplace, and having under-school-aged children), perceived neighborhood environmental problems, perceived PA barriers, and PA outcomes.

PA was assessed by the International Physical Activity Questionnaire short form (IPAQ short) [38]. Three important types of PA outcomes, namely, vigorous physical activity (VPA), moderate physical activity (MPA), and prolonged sitting, were dummy variables based on the responses to the following questions: "During the past week, did you do vigorous physical activities such as heavy lifting, digging, aerobics, or fast bicycling for at least $10 \mathrm{~min}$ at a time?", "During the past week, did you do moderate physical activities, not including walking, such as carrying light loads, bicycling at a regular pace, or playing doubles tennis?" and "During the past week, did you spend longer than $6 \mathrm{~h}$ sitting on a weekday?". Affirmative responses were coded as 1 . In the sensitivity analysis, two other forms of PA outcomes were also used, including continuous measures of VPA and MPA based on the IPAQ short using minutes per week, with dummy measures of VPA 
for performing at least 75 min VPA a week and MPA for performing at least 150 min MPA a week.

Perceived PA barriers were assessed by asking respondents "During the past month, have you encountered any barrier when you do/plan to do physical activities?". The following 14 potential PA barriers were provided for respondents: never thought of doing exercise; no spare time/too busy; feeling tired; falling sick; injured; physical limitations; no companion; no facilities/space nearby; do not know how to do physical activities; no persistence; laziness; bad air quality; others (please specify). Affirmative responses for each PA barrier were coded as 1, and 14 variables related with each PA barrier were produced. We also produced a composite variable, having barrier, coded as 1 for reporting one of above PA barriers and 0 for reporting none of above PA barriers.

Perceived neighborhood environmental problems were estimated by asking respondents "Do you think that any of the things are a problem in this area?". The following 12 potential environmental problems were provided for respondents: poor street lighting or broken pavements; noise (e.g., traffic, business); noisy neighbors or loud parties; air pollution; lack of open public spaces; risk from traffic for pedestrians and cyclists; illegal parking (e.g., on pavements); people being drunk or rowdy in the street/park; criminal activity (e.g., burglary, robbery, assault or vandalism); problems with communal areas (e.g., rubbish in corridors/lift(s) not working); and others (please specify). Affirmative responses for each environmental problem were coded as 1 . Therefore, 12 variables related with each perceived neighborhood environmental problem were produced.

\subsection{Objective Built Environment Measures}

Four objective environmental measures about neighborhood public leisure facilities (gym density, park density, recreation facility density, sports facility density) were used. Data on public leisure facilities were collected from the Leisure and Cultural Service Department (LCSD), Hong Kong (accessed on 1 August 2019, https: / / www.lcsd.gov.hk). These public leisure facilities were re-categorized into four types (Gym, Park, Recreation Facility, Sports Facility) based on the study theme and their potential influence on different types of PA behaviors (Table 1). A Gym was defined as a fitness room; a Park was a park, a zoo, or a garden; a Recreation Facility was a community hall or center, a museum, a library, a performance venue, or a barbecue area; and a Sports Facility was a sports center, a recreation ground, a swimming pool, or a sports ground. We did not individually list leisure or sports facilities because they are provided by the relevant place. The addresses of the public leisure facilities were geocoded to obtain the latitude and longitude using a Google Maps application programming interface (API). The density of each type of public facility was calculated in ArcGIS 10.4.1 using the buffer and the count points in polygon analysis tools.

Street centrality was a composite index calculated for each respondent by gathering four related indicators (reach, betweenness, straightness, and intersection density) based on the following formula: Z-score (Z-score (reach) + Z-score (betweenness) + Z-score (straightness) + Z-score (intersection density)). Data on street networks were obtained from the Transport Department, the Government of Hong Kong Special Administrative Region, and comprised two network elements (nodes and edges). The first three indicators (reach, betweenness, and straightness) were calculated in the Urban Network Analysis (UNA) toolbox in ArcGIS 10.4.1 with the Network Analyst Extension [36]. There were two steps in the calculation of these three indicators (reach, betweenness, and straightness) for each respondent, as follows: (1) the assignment of metrics to each street node with a $1 \mathrm{~km}$ Euclidean distance radius; and (2) the calculation of the mean centrality score for each respondent with respect to all of the street nodes within a buffer around the respondent's home. Intersection density was calculated as the number of intersections within a buffer around a respondent's home. For each environmental measure (gym density, park density, recreation facility density, sports facility density, and street centrality), a range of buffer sizes $(0.5 \mathrm{~km}, 1 \mathrm{~km}, 1.5 \mathrm{~km}, 2 \mathrm{~km}, 2.5 \mathrm{~km}, 3 \mathrm{~km}, 5 \mathrm{~km}$, and $8 \mathrm{~km})$ around a 
respondent's home were used. All the environmental measures were standardized to Z-scores with a distribution, with a mean of 0 and a standard deviation (SD) of 1 for logistic regression analyses.

Table 1. Four new categories of public leisure facilities.

\begin{tabular}{ccc}
\hline New Category & List & Number \\
\hline Gym & Fitness Rooms & 70 \\
\hline Park & Park & 56 \\
\hline Recreation Facility & Community Halls and Community Centers & 106 \\
& Museums & 18 \\
& Libraries & 183 \\
& Performing Venues & 17 \\
& Barbecue Areas & 46 \\
\hline Sports Facility & Sports Centers & 101 \\
& Recreation Grounds & 339 \\
& Water Sports Centers & 5 \\
& Swimming Pools & 45 \\
\end{tabular}

\subsection{Statistical Analyses}

In the main statistical analyses, we used a $1 \mathrm{~km}$ buffer size, as this refers to an acceptable 15 min walking distance that is commonly used in the literature [39]. All the objective environmental variables are continuous variables (Z-score), and the other variables are categorical variables. The statistical tests were two tailed, with a significance level of 0.05 . Unstandardized regression coefficients (B), standard errors (SE), odds ratios (ORs), 95\% confidence intervals (CIs), and probability (P) were obtained. The statistical package SPSS version 20 (SPSS Inc., Chicago, IL, USA) was used for analyses.

For the first objective (i.e., the independent association between the specific type of public leisure facilities (gym, park, recreation, and sports) and street centrality with PA behaviors), we used logistic regression models to estimate the odds ratios of engaging in VPA, MPA, or prolonged sitting with regard to an SD increase for the objective environmental variables. The dependent variables were VPA, MPA, and prolonged sitting, while the independent variables were each objective environmental variable (gym density, park density, recreation facility density, sports facility density and street centrality) and covariates. Three kinds of models were computed for each environmental variable. Model 1 contained only one environmental measure and no other covariates. Model 2 adjusted for significant socio-demographic covariates and perceived PA barriers. Model 3 adjusted for significant socio-demographic covariates, perceived PA barriers, and significant perceived neighborhood environment problems. There are 10 missing values related with variables of perceived PA barriers, and those samples were removed from the model 2 and model 3 calculation. To evaluate the robustness of our results from a $1 \mathrm{~km}$ sized buffer, we repeated our analyses of the associations of environmental variables with VPA, MPA, and prolonged sitting with other buffers $(0.5 \mathrm{~km}, 1.5 \mathrm{~km}, 2 \mathrm{~km}, 2.5 \mathrm{~km}, 3 \mathrm{~km}, 5 \mathrm{~km}$, and $8 \mathrm{~km})$. In addition, we performed sensitivity analyses with different VPA and MPA measures.

The second objective of this study was to examine how the associations between street centrality and PA behaviors were mediated by public leisure facilities. We used mediation analyses (Figure 1) and logistic regression models to test the associations. The mediation models were adjusted for significant socio-demographic covariates, perceived PA barriers, and significant perceived neighborhood environment problems. The indirect effect of street centrality on PA outcomes through the mediators (public leisure facilities) can be calculated as the product of the coefficients for path $A$ and $B(a \times b)$, with the total effect being $a \times b+c^{\prime}$. The mediation effect was calculated as $(a \times b) /\left(a \times b+c^{\prime}\right)$, and presented as percentage [40]. To test whether the indirect effect was significant, we followed the 
methods of Preacher and Hayes [41]. Standardized coefficients from the logistic regressions were used to assess the mediation, and odds ratios are shown for descriptive purposes.

The third objective was to find out whether the associations of the built environmental variables (including public leisure facilities and street centrality) with PA differed in people who perceived different PA barriers. Based on the results of the first objective, we added interaction terms between each perceived PA barrier and sports facility density in the regression models to statistically test whether the perceived barriers modify the association between sports facility density and MPA. Only the significant interactions between barriers and sports facility density had been reserved. Then, we used stratified models to explore how the associations changed across the strata.

\section{Results}

This sample included 477 (24.1\%) young adults (aged 18-39), 804 (40.7\%) middleaged persons (aged 40-59), and 696 (35.2\%) older persons (aged 60 or over). Among the respondents, $58.9 \%$ were female, $57.1 \%$ lived in public rental housing, $26.7 \%$ were low income ( $<$ HKD3500), $24.1 \%$ were self-reported poor, $85.4 \%$ had not attended university, $38.2 \%$ were unmarried, $51.6 \%$ were not born in Hong Kong, and $91.7 \%$ did not have underschool-aged children. These demographics were similar to those for Hong Kong as a whole in the census data [7], which shows the representativeness of the sample.

Additionally, more than half of the respondents $(66.7 \%)$ were reported to be satisfied with their neighborhood environment. Rats or insects $(20.2 \%)$, noise $(15.5 \%)$, and air pollution (9\%) were the top three perceived neighborhood environmental problems, and $53.3 \%$ of respondents reported no neighborhood environmental problems. In addition, among the 14 potential PA barriers, "no spare time/too busy" $(25.6 \%)$, "felt tired" (20\%) and "never thought of doing PA" (11.1\%) were the top three perceived PA barriers, and $38.8 \%$ reported no barriers. Among the 1977 respondents, $72.7 \%$ had not performed $10 \mathrm{~min}$ of VPA during the past week, $47.5 \%$ had not performed any MPA in the past week, and $56.9 \%$ had sat for longer than $6 \mathrm{~h}$ on a weekday.

\subsection{Descriptive Statistics of the Objective Built Environmental Measures}

Collectively, the surveyed Hong Kong adults had a mean (SD) of 1.26 (0.96) gyms, 0.75 (0.88) parks, 5.68 (2.84) recreation facilities, and 7.77 (4.91) sports facilities within a $1 \mathrm{~km}$ buffer around their homes. The descriptive statistics of public leisure facilities and street centrality stratified by perceived neighborhood environment and house type are shown in Table 2. The subsample of respondents who perceived no neighborhood problems lived in areas with a higher mean (SD) of public leisure facilities than the whole sample, with 1.35 (0.94) gyms, $0.86(0.93)$ parks, 6.10 (2.50) recreation facilities, and 7.88 (4.83) sports facilities. Respondents who perceived the neighborhood environmental problem of rats and insects lived in areas with a lower mean (SD) of built environment measures than the whole population: $0.87(0.91)$ gyms, 0.51 (0.68) parks, 3.88 (3.13) recreation facilities, 6.16 (4.82) sports facilities, and -0.22 (0.97) street centrality. Neighborhoods with a perceived problem of noise (e.g., traffic, business), air pollution, or people being drunk or rowdy in the street/park had a higher sports facility density and street centrality than the whole sample. Respondents living in public rental housing had a higher density of public leisure facilities and street centrality in their areas. We also used a non-parametric MannWhitney test to investigate whether populations who perceived specific neighborhood environmental problems had the same distribution of built environment features as populations who did not perceive specific neighborhood environmental problems. The results showed a sub-population who reported a lack of open public spaces had no significant difference in the density of public leisure facilities. 
Table 2. Descriptive statistics of public leisure facilities and street centrality stratified by perceived neighborhood environment and house type.

\begin{tabular}{|c|c|c|c|c|c|c|c|}
\hline & & & $\begin{array}{c}\text { Gym } \\
\text { Density }\end{array}$ & Park Density & $\begin{array}{c}\text { Recreation } \\
\text { Facility Density }\end{array}$ & $\begin{array}{c}\text { Sports } \\
\text { Facility Density }\end{array}$ & $\begin{array}{c}\text { Street } \\
\text { Centrality }\end{array}$ \\
\hline & Code & $\mathbf{N}(\%)$ & & & Mean (SD) & & \\
\hline General population & & $1977(100)$ & $1.26(0.96)$ & $0.75(0.89)$ & $5.68(2.84)$ & $7.77(4.91)$ & $0.00(1.00)$ \\
\hline Poor street lighting or broken pavements & $\begin{array}{l}1 \\
0\end{array}$ & $\begin{array}{c}97(4.9) \\
1880(95.1)\end{array}$ & $\begin{array}{l}1.28(0.91) \\
1.26(0.96)\end{array}$ & $\begin{array}{l}0.44(0.61) \\
0.77(0.89)\end{array}$ & $\begin{array}{l}5.29(3.47) \\
5.70(2.81)\end{array}$ & $\begin{array}{l}5.62(3.73) \\
7.88(4.94)\end{array}$ & $\begin{array}{c}-0.13(0.88) \\
0.00(1.01)\end{array}$ \\
\hline Noise (e.g., traffic, business) & $\begin{array}{l}1 \\
0\end{array}$ & $\begin{array}{c}307(15.5) \\
1670(84.5)\end{array}$ & $\begin{array}{l}1.28(0.95) \\
1.25(0.96)\end{array}$ & $\begin{array}{l}0.72(0.86) \\
0.76(0.89)\end{array}$ & $\begin{array}{l}6.01(2.71) \\
5.61(2.86)\end{array}$ & $\begin{array}{l}\mathbf{9 . 1 5}(5.33) \\
7.51(4.79)\end{array}$ & $\begin{array}{c}\mathbf{0 . 3 7}(\mathbf{1 . 2 0}) \\
-0.07(0.94)\end{array}$ \\
\hline Noisy neighbors or loud parties & $\begin{array}{l}1 \\
0\end{array}$ & $\begin{array}{c}159(8) \\
1818(92)\end{array}$ & $\begin{array}{l}1.39(0.93) \\
1.25(0.96)\end{array}$ & $\begin{array}{l}0.72(0.89) \\
0.76(0.88)\end{array}$ & $\begin{array}{l}6.22(2.64) \\
5.63(2.85)\end{array}$ & $\begin{array}{l}8.19(4.91) \\
7.73(4.91)\end{array}$ & $\begin{array}{c}0.14(1.12) \\
-0.01(0.99) \\
\end{array}$ \\
\hline Air pollution & $\begin{array}{l}1 \\
0\end{array}$ & $\begin{array}{c}178(9) \\
1799(91)\end{array}$ & $\begin{array}{l}1.28(1.02) \\
1.26(0.95)\end{array}$ & $\begin{array}{l}0.71(0.88) \\
0.76(0.88)\end{array}$ & $\begin{array}{l}5.60(2.86) \\
5.68(2.84)\end{array}$ & $\begin{array}{l}9.40(5.38) \\
7.60(4.83)\end{array}$ & $\begin{array}{c}\mathbf{0 . 3 8}(\mathbf{1 . 1 6 )} \\
-0.04(0.98) \\
\end{array}$ \\
\hline Lack of open public spaces & $\begin{array}{l}1 \\
0\end{array}$ & $\begin{array}{c}82(4.1) \\
1895(95.9)\end{array}$ & $\begin{array}{l}1.13(0.90) \\
1.26(0.96)\end{array}$ & $\begin{array}{l}0.70(0.93) \\
0.76(0.88)\end{array}$ & $\begin{array}{l}5.70(2.95) \\
5.68(2.84)\end{array}$ & $\begin{array}{l}7.77(4.82) \\
7.77(4.92)\end{array}$ & $\begin{array}{l}0.16(0.98) \\
0.00(1.00)\end{array}$ \\
\hline Risk from traffic for pedestrians and cyclists & $\begin{array}{l}1 \\
0\end{array}$ & $\begin{array}{c}46(2.3) \\
1931(97.7)\end{array}$ & $\begin{array}{l}1.24(1.02) \\
1.26(0.96)\end{array}$ & $\begin{array}{l}0.37(0.57) \\
0.76(0.89)\end{array}$ & $\begin{array}{l}5.37(3.15) \\
5.68(2.83)\end{array}$ & $\begin{array}{l}7.24(4.42) \\
7.78(4.92)\end{array}$ & $\begin{array}{c}-0.01(0.87) \\
0.00(1.00)\end{array}$ \\
\hline Illegal parking (e.g., on pavements) & $\begin{array}{l}1 \\
0\end{array}$ & $\begin{array}{c}97(4.9) \\
1880(95.1) \\
\end{array}$ & $\begin{array}{l}1.37(0.98) \\
1.25(0.96)\end{array}$ & $\begin{array}{l}0.53(0.76) \\
0.76(0.89)\end{array}$ & $\begin{array}{l}5.49(3.20) \\
5.69(2.82)\end{array}$ & $\begin{array}{l}7.00(4.58) \\
7.81(4.93) \\
\end{array}$ & $\begin{array}{c}-0.10(0.89) \\
0.00(1.01)\end{array}$ \\
\hline People drunk or rowdy in the street/park & $\begin{array}{l}1 \\
0\end{array}$ & $\begin{array}{c}88(4.5) \\
1889(95.5) \\
\end{array}$ & $\begin{array}{l}1.41(0.93) \\
1.25(0.96)\end{array}$ & $\begin{array}{l}0.70(0.86) \\
0.76(0.88)\end{array}$ & $\begin{array}{l}5.83(2.41) \\
5.67(2.86)\end{array}$ & $\begin{array}{l}8.50(4.17) \\
7.73(4.94) \\
\end{array}$ & $\begin{array}{l}\mathbf{0 . 2 0}(\mathbf{0 . 9 3}) \\
0.00(1.00) \\
\end{array}$ \\
\hline Criminal activity (e.g., burglary, robbery) & $\begin{array}{l}1 \\
0\end{array}$ & $\begin{array}{c}89(4.5) \\
1888(95.5) \\
\end{array}$ & $\begin{array}{l}1.31(0.83) \\
1.26(0.97) \\
\end{array}$ & $\begin{array}{l}0.62(0.82) \\
0.76(0.89)\end{array}$ & $\begin{array}{l}5.90(2.88) \\
5.67(2.84)\end{array}$ & $\begin{array}{l}8.52(5.16) \\
7.73(4.90)\end{array}$ & $\begin{array}{c}0.27(1.02) \\
-0.01(1.00)\end{array}$ \\
\hline Problems with communal areas (e.g., rubbish) & $\begin{array}{l}1 \\
0 \\
\end{array}$ & $\begin{array}{c}97(4.9) \\
1880(95.1) \\
\end{array}$ & $\begin{array}{l}1.29(0.92) \\
1.26(0.96)\end{array}$ & $\begin{array}{l}0.68(0.86) \\
0.76(0.88)\end{array}$ & $\begin{array}{l}6.33(2.61) \\
5.64(2.85) \\
\end{array}$ & $\begin{array}{l}8.10(4.36) \\
7.75(4.94) \\
\end{array}$ & $\begin{array}{l}0.08(0.98) \\
0.00(1.00)\end{array}$ \\
\hline Rats or insects & $\begin{array}{l}1 \\
0\end{array}$ & $\begin{array}{c}400(20.2) \\
1577(79.8)\end{array}$ & $\begin{array}{l}\mathbf{0 . 8 7}(\mathbf{0 . 9 1 )} \\
1.36(0.95)\end{array}$ & $\begin{array}{l}\mathbf{0 . 5 1}(\mathbf{0 . 6 8 )} \\
0.81(0.92)\end{array}$ & $\begin{array}{l}3.88(3.13) \\
6.13(2.57)\end{array}$ & $\begin{array}{l}\mathbf{6 . 1 6}(4.82) \\
8.17(4.85)\end{array}$ & $\begin{array}{c}-\mathbf{0 . 2 2}(\mathbf{0 . 9 7 )} \\
0.06(1.00)\end{array}$ \\
\hline None of these & $\begin{array}{l}1 \\
0\end{array}$ & $\begin{array}{l}1051(53.2) \\
923(46.7)\end{array}$ & $\begin{array}{l}1.35(0.94) \\
1.16(0.98)\end{array}$ & $\begin{array}{l}\mathbf{0 . 8 6}(\mathbf{0 . 9 3 )} \\
0.63(0.81)\end{array}$ & $\begin{array}{l}6.10(2.50) \\
5.19(3.12)\end{array}$ & $\begin{array}{l}7.88(4.83) \\
7.63(5.00)\end{array}$ & $\begin{array}{c}-\mathbf{0 . 0 2 ( 0 . 9 8 )} \\
0.02(1.02)\end{array}$ \\
\hline \multicolumn{8}{|l|}{ House type } \\
\hline $\begin{array}{l}\text { Non-public rental housing } \\
\text { Public rental housing }\end{array}$ & & $\begin{array}{r}848(42.9) \\
1129(57.1)\end{array}$ & $\begin{array}{l}1.11(1.02) \\
1.37(0.90)\end{array}$ & $\begin{array}{l}0.60(0.78) \\
0.87(0.93)\end{array}$ & $\begin{array}{l}4.82(3.14) \\
6.32(2.40)\end{array}$ & $\begin{array}{l}6.88(4.62) \\
8.43(5.02)\end{array}$ & $\begin{array}{c}-0.06(0.96) \\
\mathbf{0 . 0 4}(\mathbf{1 . 0 3 )}\end{array}$ \\
\hline
\end{tabular}

Important information is bold to make the comprehension of the table easier. 


\subsection{Logistic Models with Objective Built Environmental Measures}

Table 3 shows the associations between five objective built environmental measures and PA outcomes. Gym density was significantly associated with VPA, and the association was not significant after controlling for perceived neighborhood environment. All four types of public leisure facilities (Gym, Park, Recreation, Sports) and street centrality were significantly positively associated with MPA; however, after controlling for covariates, only sports facility density and street centrality had significant positive associations with MPA. Among the five built environmental measures, only recreation facility density showed no significant association with prolonged sitting after controlling for covariates. Tables S1 and S2 in Supplementary shows the sensitivity analysis results based on the different buffer sizes and different forms of PA outcomes. The associations of these five built environment measures with PA behaviors increased with the buffer size. Gym density showed a positive significant association with VPA for at least 75 min a week.

Table 3. Logistic regression model results with public leisure facilities and street centrality.

\begin{tabular}{|c|c|c|c|c|}
\hline Outcome & Exposure & Model 1 & Model 2 & Model 3 \\
\hline & & OR $(95 \% \mathrm{CI})$ & OR $(95 \%$ CI $)$ & OR $(95 \%$ CI $)$ \\
\hline \multirow{5}{*}{ VPA } & Gym Density & $1.18(1.07,1.30)^{* * *}$ & $1.11(1.00,1.24)$ * & $1.06(0.95,1.18)$ \\
\hline & Park Density & $0.94(0.85,1.04)$ & $0.95(0.85,1.05)$ & $0.93(0.83,1.04)$ \\
\hline & $\begin{array}{l}\text { Recreation } \\
\text { Density }\end{array}$ & $1.07(0.97,1.18)$ & $1.08(0.97,1.20)$ & $0.99(0.88,1.11)$ \\
\hline & Sports Density & $1.00(0.91,1.11)$ & $1.01(0.91,1.12)$ & $0.97(0.87,1.08)$ \\
\hline & Street Centrality & $0.99(0.90,1.10)$ & $1.01(0.91,1.12)$ & $0.98(0.88,1.09)$ \\
\hline \multirow{5}{*}{ MPA } & Gym Density & $1.13(1.03,1.23)$ ** & $1.08(0.99,1.19)$ & $1.06(0.96,1.16)$ \\
\hline & Park Density & $1.10(1.00,1.20) *$ & $1.06(0.97,1.16)$ & $1.06(0.96,1.16)$ \\
\hline & $\begin{array}{l}\text { Recreation } \\
\text { Density }\end{array}$ & $1.20(1.10,1.31)^{* * *}$ & $1.13(1.03,1.25)$ * & $1.10(0.99,1.21)$ \\
\hline & Sports Density & $2.33(2.08,2.60)^{* * *}$ & $2.29(2.04,2.57)^{* * *}$ & $2.26(2.01,2.53)^{* * *}$ \\
\hline & Street Centrality & $2.35(2.08,2.64)^{* * *}$ & $2.31(2.04,2.61)^{* * *}$ & $2.26(2.00,2.56)$ \\
\hline \multirow{5}{*}{$\begin{array}{l}\text { Prolonged } \\
\text { Sitting }\end{array}$} & Gym Density & $1.11(1.01,1.21)$ * & $1.11(1.01,1.22) *$ & $1.11(1.01,1.22)$ * \\
\hline & Park Density & $0.89(0.81,0.97)$ * & $0.89(0.81,0.98)$ * & $0.89(0.81,0.98)$ * \\
\hline & $\begin{array}{l}\text { Recreation } \\
\text { Density }\end{array}$ & $1.01(0.93,1.11)$ & $1.03(0.94,1.12)$ & $1.02(0.93,1.12)$ \\
\hline & Sports Density & $1.32(1.21,1.44)^{* * *}$ & $1.32(1.20,1.45)^{* * *}$ & $1.31(1.19,1.44)^{* * *}$ \\
\hline & Street Centrality & $1.27(1.16,1.39)^{* * *}$ & $1.26(1.15,1.38)^{* * *}$ & $1.25(1.14,1.37)^{* * *}$ \\
\hline
\end{tabular}

Notes: ${ }^{*} p<0.05,{ }^{* *} p<0.01,{ }^{* * *} p<0.001$. Model 1 contained only the objective environment measures and no other covariates. Model 2 adjusted for significant socio-demographic covariates (age, sex, marital status, house type, self-reported poverty level, monthly income (equivalized household income), education attainment, birthplace, and having under-school-aged children) and perceived PA barriers. Model 3 adjusted for significant socio-demographic covariates (age, sex, marital status, house type, self-reported poverty level, monthly income (equivalized household income), education attainment, birthplace, and having under-school-aged children), perceived PA barriers, and significant perceived neighborhood environment problems. There are $10 \mathrm{missing}$ values related with variables of perceived PA barriers, and those samples were removed from the model 2 and model 3 calculations. The sample number in model 1 is 1977 and in model 2 and 3 is 1967.

\subsection{Mediation by Public Leisure Facilities}

Mediation analyses were performed based on the results of the independent associations between the five environmental measures and PA outcomes. Table 4 shows the coefficients and odds ratios for the mediation analyses among street centrality, public leisure facilities, and PA behaviors. There were significant positive associations between street centrality and the density of the four types of public leisure facilities (path A). Although the positive association of street centrality with MPA was reduced after adjusting for sports facility density, it was still positively significant (OR $=1.48$; $95 \%$ CI 1.24-1.78), indicating that the association between street centrality and MPA was partially mediated by sports facilities. Street centrality showed no significant association with prolonged sitting after adjusting for sports facility density, indicating that the association between street centrality and prolonged sitting was fully mediated by sports facilities. Besides, the positive association of street centrality with prolonged sitting was reduced after adjusting 
for gym density $(\mathrm{OR}=1.24 ; 95 \% \mathrm{CI} 1.13-1.37)$ and was enhanced after adjusting for park density (OR $=1.29 ; 95 \%$ CI $1.17-1.42)$.

Table 4. Mediation analyses of public leisure facilities for the associations between street centrality and PA behaviors.

\begin{tabular}{|c|c|c|c|c|c|c|}
\hline & $\begin{array}{l}\text { Street Centrality } \\
\quad \text { (path A) }\end{array}$ & \multicolumn{2}{|c|}{$\begin{array}{c}\text { MPA } \\
\text { (path B and } C^{\prime} \text { ) }\end{array}$} & \multirow[t]{2}{*}{$\begin{array}{l}\text { Indirect } \\
\text { Effect }\end{array}$} & \multirow[t]{2}{*}{$\begin{array}{c}\text { Hosmer and } \\
\text { Lemeshow } \\
\text { Test }(p)\end{array}$} & \multirow[t]{2}{*}{$\begin{array}{l}\text { Proportion } \\
\text { Mediation }\end{array}$} \\
\hline & B (SE) & B (SE) & OR $(95 \% \mathrm{CI})$ & & & \\
\hline \multirow{4}{*}{$\begin{array}{l}\text { Street Centrality } \\
\text { Sports Facility } \\
\text { Density }\end{array}$} & & $0.40(0.09)^{* * *}$ & $1.48(1.24,1.78)$ & & & \\
\hline & $0.79(0.01)^{* * *}<0.001$ & $0.52(0.09)^{* * *}$ & $1.68(1.42,2.00)$ & $0.412 * * *$ & 0.093 & $51.05 \%$ \\
\hline & $\begin{array}{l}\text { Street Centrality } \\
\text { (path A) }\end{array}$ & \multicolumn{2}{|c|}{$\begin{array}{l}\text { Prolonged Sitting } \\
\text { (path } B \text { and } C^{\prime} \text { ) }\end{array}$} & & & $\begin{array}{l}\text { Proportion } \\
\text { Mediation }\end{array}$ \\
\hline & B (SE) & B (SE) & OR $(95 \% \mathrm{CI})$ & & & \\
\hline $\begin{array}{l}\text { Street Centrality } \\
\text { Gym Density } \\
\text { Street Centrality }\end{array}$ & $0.29(0.02)^{* * *}$ & $\begin{array}{c}0.22(0.05)^{* * *} \\
0.04(0.05) \\
0.25(0.05)^{* * *}\end{array}$ & $\begin{array}{l}1.24(1.13,1.37) \\
1.04(0.95,1.14) \\
1.29(1.17,1.42)\end{array}$ & 0.011 & 0.324 & $4.82 \%$ \\
\hline $\begin{array}{l}\text { Park Density } \\
\text { Street Centrality }\end{array}$ & $0.15(0.02)^{* * *}$ & $\begin{array}{c}-0.16(0.05)^{* * *} \\
0.02(0.08)\end{array}$ & $\begin{array}{l}0.86(0.78,0.94) \\
1.02(0.88,1.19)\end{array}$ & $-0.024^{* *}$ & 0.259 & $-10.43 \%$ \\
\hline $\begin{array}{l}\text { Sports Facility } \\
\text { Density }\end{array}$ & $0.79(0.01)^{* * *}$ & $0.25(0.07)^{* * *}$ & $1.29(1.11,1.49)$ & $0.199^{* * *}$ & 0.509 & $90.05 \%$ \\
\hline
\end{tabular}

Notes: ${ }^{* *} p<0.01,{ }^{* * *} p<0.001$. Mediation models adjusted for significant socio-demographic covariates, perceived PA barriers, and significant perceived neighborhood environment problems. There are 10 missing values related with variables of perceived PA barriers, and those samples were removed. The sample number for the models is 1967. Standardized coefficients from the logistic regressions were used to assess the mediation, and odds ratios are shown for descriptive purposes. The indirect effect of street centrality on PA outcomes through the mediator (public leisure facilities) can be calculated as the product of the coefficients for paths A and B $(a \times b)$, where the total effect is $a \times b+c^{\prime}$. The mediation effect (proportion mediation) was calculated as $(a \times b) /\left(a \times b+c^{\prime}\right) \times 100 \%$. The Hosmer and Lemeshow test $(p)$ shows the fitting degree of the models. If $p>0.05$, the fit of the model is good.

\subsection{Stratified Models with Respect to Perceived PA Barriers}

Table 5 shows the results of the associations between sports facility density and MPA after adjusting for significant covariates, namely, socio-demographic variables, perceived neighborhood environmental problems, and street centrality among people who perceived different PA barriers. For those who perceived PA barriers, sports facility density had a greater positive association with MPA. For example, a one SD increase in sports facility density was associated with $36.69 \%$ higher odds of MPA for those who never thought of performing PA, $43.20 \%$ higher odds for those who fell sick, $89.94 \%$ higher odds for those who had physical limitations, and $149.70 \%$ higher odds for those who had no companion. 
Table 5. Stratified model of associations between sports facility density and MPA of respondents who perceived different PA barriers.

\begin{tabular}{|c|c|c|c|c|c|c|c|}
\hline \multirow[t]{2}{*}{ Perceived PA Barrier } & \multicolumn{3}{|c|}{ Variable $=1$} & \multicolumn{4}{|c|}{ Variable $=0$} \\
\hline & $N_{1}$ & $B_{1}(\mathrm{SE})$ & $\mathrm{OR}_{1}(95 \% \mathrm{CI})$ & $N_{2}$ & $B_{2}(\mathrm{SE})$ & $\mathrm{OR}_{2}(95 \% \mathrm{CI})$ & Gap (\%) \\
\hline $\begin{array}{l}\text { Never thought of doing } \\
\text { exercises }\end{array}$ & 230 & $0.81(0.34)$ & $2.24(1.16,4.33) *$ & 1737 & $0.48(0.09)$ & $1.62(1.35,1.94)^{* * *}$ & 36.69 \\
\hline No spare time/too busy & 428 & $0.62(0.19)$ & $1.86(1.28,2.69) * * *$ & 1540 & $0.53(0.10)$ & $1.69(1.39,2.06)^{* * *}$ & 10.06 \\
\hline Felt tired & 295 & $0.82(0.22)$ & $2.26(1.49,3.45) * * *$ & 1672 & $0.48(0.10)$ & $1.62(1.33,1.96)^{* * *}$ & 37.86 \\
\hline Fell sick & 117 & $0.87(0.43)$ & $2.39(1.04,5.49) *$ & 1850 & $0.51(0.09)$ & $1.66(1.39,1.99)^{* * *}$ & 43.20 \\
\hline Physical limitations & 105 & $1.16(0.51)$ & $3.17(1.18,8.56) *$ & 1863 & $0.50(0.09)$ & $1.65(1.38,1.96)^{* * *}$ & 89.94 \\
\hline No companion & 51 & $1.43(0.70)$ & $4.19(1.06,16.57)$ * & 1916 & $0.51(0.09)$ & $1.66(1.40,1.98)^{* * *}$ & 149.70 \\
\hline No persistence & 118 & $0.89(0.35)$ & $2.44(1.23,4.82) *$ & 1849 & $0.50(0.09)$ & $1.65(1.38,1.98)^{* * *}$ & 46.75 \\
\hline Laziness & 191 & $0.72(0.30)$ & $2.06(1.15,3.70) *$ & 1776 & $0.51(0.09)$ & $1.67(1.39,2.00)^{* * *}$ & 23.08 \\
\hline Having barrier & $\begin{array}{c}1116 \\
N\end{array}$ & $\begin{array}{l}0.64(0.12) \\
\quad B(\mathrm{SE})\end{array}$ & $\begin{array}{l}1.89(1.50,2.38) * * * \\
\text { OR }(95 \% \text { CI })\end{array}$ & 852 & $0.47(0.15)$ & $1.61(1.21,2.14)^{* * *}$ & 16.57 \\
\hline General Population & 1977 & $0.52(0.09)$ & $1.69(1.42,2.00)^{* * *}$ & & & & \\
\hline
\end{tabular}

Notes: ${ }^{*} p<0.05,{ }^{* * *} p<0.001$. Affirmative response for each PA barrier was coded as 1 and 14 variables related with each PA barrier were produced. We also produced a composite variable, having barrier, coded as 1 for reporting one of above PA barriers and as 0 for reporting none of above PA barriers. Samples with missing values were removed. Based on the results of Table 2, we added the interaction terms between each perceived PA barrier and sports facility density in the regression models to statistically test whether the perceived barriers modify the association between sports facility density and MPA. Only the significant interactions between barrier and sports facility density had been reserved. Then, we used stratified models to explore how the associations changed across the strata. The stratified model adjusted for significant socio-demographic covariates, perceived PA barriers, perceived neighborhood environment problems, and street centrality. The gap for each perceived PA barrier was calculated as $\left(\mathrm{OR}_{1}-\mathrm{OR}_{2}\right) / \mathrm{OR} \times 100 \%$.

\section{Discussion}

Using cross-sectional survey data and objective GIS-based built environment data, we found that gym density was significantly associated with VPA, but the association disappeared after controlling for covariates. Sports facility density was associated with a greater probability of MPA, and was greater in those who perceived PA barriers. Additionally, sports facility density was a partial mediator for the association between street centrality and MPA. Park density was associated with lower odds of prolonged sitting. Recreational moderate-to-vigorous physical activity ( $>150 \mathrm{~min} /$ week) was positively related to the number of recreational facilities, including parks and recreational and sports facilities, within a $1 \mathrm{~km}$ buffer among Hong Kong older adults ( $\geq 65$ years) in a previous study [42]. In this study, we have extended the findings of $\mathrm{Lu}$ et al. by showing the associations between specific PA outcomes and specific types of facilities.

After controlling for covariates, park density was not significantly associated with VPA or MPA, whereas it was associated with lower odds of prolonged sitting, indicating that living near a park could reduce sedentary behavior. It is worth noting that we did not include walking in our PA outcomes because we lacked walking data. The seemingly strange finding related with park density could be interpreted that people only walk in the park, and do not engage in VPA (such as heavy lifting, digging, aerobics, or fast bicycling) or MPA (such as carrying light loads, bicycling at a regular pace, or playing doubles tennis) in the park. Therefore, the park is only a place to reduce prolonged sitting, not a place to promote VPA or MPA. A previous study also found a similar result, whereby street greenery was positively associated with walking for Hong Kong's older adults; however, further research is needed to examine the relationships between park characteristics and walking behaviors.

Moreover, although it was found in a previous study conducted among 1078 participants aged 18-65 in Hong Kong that street connectivity in terms of intersection density was not significantly related to any domain of walking [43], we found that street centrality, a composite index formed by gathering four related indicators (reach, betweenness, straightness, and intersection density), was significantly associated with MPA. Additionally, the association of street centrality with MPA was partially mediated by sports facility density, 
highlighting the importance of sports facility density. The partially mediating role of sports facilities on the association between street centrality and MPA emphasized the application of the Theory of Natural Movement [15]. Additionally, the findings of our research enrich the existing Location Theory [17], expanding the research object from commercial land uses to public land uses. Further research related to associations among street centrality, public land uses, and human behaviors can be conducted in the future.

Furthermore, we have to be aware that street centrality and sports facility density were associated with higher prolonged sitting, which were contrary to conventional wisdom. Additionally, we found that the association of street centrality with prolonged sitting was fully mediated by sports facility density. Therefore, the statistical results showed that a higher density of sports facilities could lead to prolonged sitting. We need to admit that it is difficult to interpret; however, the possible reason could be related with narrow indoor environments. From our data, we could see that a high density of sports facilities was found more often in roadside neighborhoods with a high street centrality, a perceived problem of noise (e.g., traffic, business), and air pollution or people being drunk or rowdy in the street/park. These roadside neighborhoods could also have narrow indoor environments because of high housing and land cost. Further research with more data and a more nuanced approach is needed.

It has been found in some studies that people living in public and private housing in Hong Kong have significantly different built and social environments, and that the built environment significantly determines social environments and exerts significant effects on social contact and activity-travel behavior $[44,45]$. Our results aligned with prior findings by showing that people living in public rental housing had significantly higher densities of public leisure facilities and street centrality than people living in non-public rental housing. Furthermore, this study shows that there is some consistency between perceived neighborhood environment and built environment features. However, we did not explore the relationships between public rental housing and perceived neighborhood environmental features, as this was outside the scope of our study.

One of the strengths of our study is that we used a comprehensive individual-level survey dataset with a representative sample of 1977 adults, incorporating GIS-based built environment features. The survey dataset contained multi-dimensional measures of socioeconomic status, behaviors, attitudes, and perceived neighborhood environment, enabling us to scrutinize the relationships between individual characteristics, environment, and health behaviors. Moreover, our use of a survey dataset with precise latitude and longitude information allowed us to construct and analyze individual measures and neighborhood objective measures together. Besides, we found that the associations of built environment variables with PA differed in people who perceived different PA barriers by using stratified models. The association of sports facility density with MPA was greater for people who had never thought of performing exercise. Our findings highlight the importance of sports facilities.

The limitations of the study are its cross-sectional design, which limits causal inference, and a lack of data on the walking behavior of the respondents and information on the actual visiting of facilities. As we used cross-sectional observational data, attitude-induced residential self-selection is also an important problem in this research, which meant that residential location was not randomly assigned, but was a "self-selected" result. However, to mitigate this problem, we included PA attitude-related variables as covariates, e.g., different perceived PA barriers, such as "never thought of doing exercise", "no spare time/too busy", "feeling tired", and so on. In addition, we focused on PA intensity levels: VPA, MPA, and sitting, while most previous PA studies have focused on walking behaviors. Due to the lack of walking data in this dataset, we could not compare our results with other walking behavior studies. Although we assessed PA with the International Physical Activity Questionnaire short form, which is the most widely used PA questionnaire based on a global standard, self-reported PA behaviors could be another limitation. Further studies should be conducted to assess PA behaviors more comprehensively and objectively, as PA is a complex 
behavior comprising different purposes, types, and intensity levels [46]. Moreover, we did not consider other objective environmental features, such as population density, land use mix, or greenness. With the development of deep learning technologies and free Google Street View images, an increasing number of studies include assessments of street-level greenery and their associations with health-related outcomes, such as depression [47], physical activity [48], cycling behaviors [49], and walking behaviors [41]. Further research is needed to probe the associations between street-level greenery and multi-dimensional healthy behaviors in Hong Kong. Furthermore, the mediation analysis we used comes with several assumptions and considerations about causal mechanisms that might bias the estimation of mediation effects when one or more assumptions are violated (e.g., exposureinduced mediator-outcome confounding) [50,51].

\section{Conclusions}

Our study provides evidence of the associations between the built environment and PA behaviors among Hong Kong adults. Several environmental factors that are linked to public leisure facilities and street layout can encourage people to undertake more active activities. Specific types of public leisure facility influence PA directly, and are also a mediator between street centrality and PA. Thus, while it is not easy to change street layout, it is possible and important for local governments to provide more sports facilities (including sports centers, recreation grounds, swimming pools, and sports grounds) and park areas to create active built environment. The government should set stricter standards for neighborhood public leisure facilities. Further research is needed to examine the associations between other environmental features, such as street-level greenery, and multi-dimensional healthy behaviors in Hong Kong.

Supplementary Materials: The following are available online at https:/ /www.mdpi.com/article/10 .3390/land11020243/s1, Table S1: Sensitivity analyses results based on different buffer sizes; Table S2: Sensitivity analyses results based on different forms of PA outcomes.

Author Contributions: Conceptualization, T.Z. and B.H.; methodology, T.Z.; software, T.Z.; validation, T.Z.; writing—original draft preparation, T.Z.; writing—review and editing, T.Z., B.H., H.W., S.Y.-S.W., and R.Y.-N.C.; visualization, T.Z.; supervision, B.H.; project administration, H.W.; funding acquisition, H.W. All authors have read and agreed to the published version of the manuscript.

Funding: The work described in this article was fully supported by a grant from the Central Policy Unit of the Government of the Hong Kong Special Administrative Region and the Research Grants Council of the Hong Kong Special Administrative Region, China (Project 4003-SPPR-11).

Conflicts of Interest: The authors declare no conflict of interest.

\section{References}

1. World Health Organization. Global Recommendations on Physical Activity for Health. Available online: https:/ /www.who.int/ publications/i/item/9789241599979 (accessed on 12 August 2020).

2. United Nations Human Development Report. 2019. Available online: http://hdr.undp.org/ (accessed on 12 August 2020).

3. Stappers, N.; Van Kann, D.; Ettema, D.; De Vries, N.K.; Kremers, S. The effect of infrastructural changes in the built environment on physical activity, active transportation and sedentary behavior-A systematic review. Health Place 2018, 53, 135-149. [CrossRef] [PubMed]

4. Wang, Y.; Chau, C.K.; Ng, W.Y.; Leung, T.M. A review on the effects of physical built environment attributes on enhancing walking and cycling activity levels within residential neighborhoods. Cities 2016, 50, 1-15. [CrossRef]

5. Sallis, J.F.; Cerin, E.; Conway, T.L.; Adams, M.A.; Frank, L.D.; Pratt, M.; Salvo, D.; Schipperijn, J.; Smith, G.; Cain, K.L.; et al. Physical activity in relation to urban environments in 14 cities worldwide: A cross-sectional study. Lancet 2016, 387, 2207-2217. [CrossRef]

6. Barnett, D.W.; Barnett, A.; Nathan, A.; Van Cauwenberg, J.; Cerin, E. Built environmental correlates of older adults' total physical activity and walking: A systematic review and meta-analysis. Int. J. Behav. Nutr. Phys. Act. 2017, 14, 103-127. [CrossRef] [PubMed]

7. Census and Statistics Department of the Government of the Hong Kong Special Administrative Region. 2020. Available online: censtatd.gov.hk/ (accessed on 12 August 2020). 
8. Cerin, E.; Lee, K.; Barnett, A.; Sit, C.H.; Cheung, M.; Chan, W.; Johnston, J.M. Walking for transportation in Hong Kong Chinese urban elders: A cross-sectional study on what destinations matter and when. Int. J. Behav. Nutr. Phys. Act. 2013, 10, 78-88. [CrossRef] [PubMed]

9. Cerin, E.; Sit, C.H.; Barnett, A.; Johnston, J.M.; Cheung, M.; Chan, W. Ageing in an ultra-dense metropolis: Perceived neighbourhood characteristics and utilitarian walking in Hong Kong elders. Public Health Nutr. 2014, 17, 225-232. [CrossRef] [PubMed]

10. Lu, Y.; Chen, L.; Yang, Y.; Gou, Z. The association of built environment and physical activity in older adults: Using a citywide public housing scheme to reduce residential self-selection bias. Int. J. Environ. Res. Public Health 2018, 15, 1973. [CrossRef] [PubMed]

11. Koohsari, M.J.; Sugiyama, T.; Lamb, K.E.; Villanueva, K.; Owen, N. Street connectivity and walking for transport: Role of neighborhood destinations. Prev. Med. 2014, 66, 118-122. [CrossRef]

12. Koohsari, M.J.; Owen, N.; Cole, R.; Mavoa, S.; Oka, K.; Hanibuchi, T.; Sugiyama, T. Built environmental factors and adults' travel behaviors: Role of street layout and local destinations. Prev. Med. 2017, 96, 124-128. [CrossRef]

13. Ettema, D.; Nieuwenhuis, R. Residential self-selection and travel behaviour: What are the effects of attitudes, reasons for location choice and the built environment? J. Transp. Geogr. 2017, 59, 146-155. [CrossRef]

14. Kilanowski, J.F. Breadth of the socio-ecological model. J. Agromed. 2017, 22, 295-297. [CrossRef] [PubMed]

15. Hillier, B.; Penn, A.; Hanson, J.; Grajewski, T.; Xu, J. Natural movement: Or, configuration and attraction in urban pedestrian movement. Environ. Plan. B Plan. Des. 1993, 20, 29-66. [CrossRef]

16. Porta, S.; Crucitti, P.; Latora, V. Multiple centrality assessment in Parma: A network analysis of paths and open spaces. Urban Des. Int. 2008, 13, 41-50. [CrossRef]

17. Ozuduru, B.H.; Webster, C.J.; Chiaradia, A.J.; Yucesoy, E. Associating street-network centrality with spontaneous and planned subcentres. Urban Stud. 2020, 58, 2059-2078. [CrossRef]

18. Al-Saaidy, H.J.; Alobaydi, D. Studying street centrality and human density in different urban forms in Baghdad, Iraq. Ain Shams Eng. J. 2021, 12, 1111-1121. [CrossRef]

19. Wang, F.; Antipova, A.; Porta, S. Street centrality and land use intensity in Baton Rouge, Louisiana. J. Transp. Geogr. 2011, 19, 285-293. [CrossRef]

20. Berghauser Pont, M.; Stavroulaki, G.; Bobkova, E.; Gil, J.; Marcus, L.; Olsson, J.; Sun, K.; Serra, M.; Hausleitner, B.; Dhanani, A.; et al. The spatial distribution and frequency of street, plot and building types across five European cities. Environ. Plan. B Urban Anal. City Sci. 2019, 46, 1226-1242. [CrossRef]

21. Wang, F.; Chen, C.; Xiu, C.; Zhang, P. Location analysis of retail stores in Changchun, China: A street centrality perspective. Cities 2014, 41, 54-63. [CrossRef]

22. Porta, S.; Latora, V.; Wang, F.; Rueda, S.; Strano, E.; Scellato, S.; Cardillo, A.; Belli, E.; Càrdenas, F.; Cormenzana, B.; et al. Street centrality and the location of economic activities in Barcelona. Urban Stud. 2012, 49, 1471-1488. [CrossRef]

23. Han, Z.; Cui, C.; Miao, C.; Wang, H.; Chen, X. Identifying spatial patterns of retail stores in road network structure. Sustainability 2019, 11, 4539. [CrossRef]

24. Rui, Y.; Ban, Y. Exploring the relationship between street centrality and land use in Stockholm. Int. J. Geogr. Inf. Sci. 2014, 28, 1425-1438. [CrossRef]

25. Li, Q.; Zhou, S.; Wen, P. The relationship between centrality and land use patterns: Empirical evidence from five Chinese metropolises. Comput. Environ. Urban Syst. 2019, 78, 101356. [CrossRef]

26. Stanilov, K. Accessibility and land use: The case of suburban Seattle, 1960-1990. Reg. Stud. 2003, 37, 783-794. [CrossRef]

27. Xiao, Y.; Sarkar, C.; Webster, C.; Chiaradia, A.; Lu, Y. Street network accessibility-based methodology for appraisal of land use master plans: An empirical case study of Wuhan, China. Land Use Policy 2017, 69, 193-203. [CrossRef]

28. Liu, Y.; Wei, X.; Jiao, L.; Wang, H. Relationships between street centrality and land use intensity in Wuhan, China. J. Urban Plan. Dev. 2016, 142, 05015001. [CrossRef]

29. Saraiva, M.; Barros, J. Exploring land-use and urban morphology in Southern Brazil using accessibility and centrality measures. Education 2016, 4, 05.

30. Jing, Y.; Liu, Y.; Cai, E.; Liu, Y.; Zhang, Y. Quantifying the spatiality of urban leisure venues in Wuhan, Central China-GIS-based spatial pattern metrics. Sustain. Cities Soc. 2018, 40, 638-647. [CrossRef]

31. He, S.; Yu, S.; Wei, P.; Fang, C. A spatial design network analysis of street networks and the locations of leisure entertainment activities: A case study of Wuhan, China. Sustain. Cities Soc. 2019, 44, 880-887. [CrossRef]

32. Liu, Y.; Zhang, Y.; Jin, S.T.; Liu, Y. Spatial pattern of leisure activities among residents in Beijing, China: Exploring the impacts of urban environment. Sustain. Cities Soc. 2020, 52, 101806. [CrossRef]

33. Cui, C.; Wang, J.; Wu, Z.; Ni, J.; Qian, T. The socio-spatial distribution of leisure venues: A case study of karaoke bars in Nanjing, China. ISPRS Int. J. Geo-Inf. 2016, 5, 150. [CrossRef]

34. Lang, W.; Chen, T.; Chan, E.H.; Yung, E.H.; Lee, T.C. Understanding livable dense urban form for shaping the landscape of community facilities in Hong Kong using fine-scale measurements. Cities 2019, 84, 34-45. [CrossRef]

35. Lang, W.; Hui, E.C.; Chen, T.; Li, X. Understanding livable dense urban form for social activities in transit-oriented development through human-scale measurements. Habitat Int. 2020, 104, 102238. [CrossRef]

36. Sevtsuk, A.; Mekonnen, M. Urban network analysis. Rev. Int. Géomatique 2012, 22, 287-305. [CrossRef] 
37. Lau, M.; Bradshaw, J. Material well-being, social relationships and children's overall life satisfaction in Hong Kong. Child Indic. Res. 2018, 11, 185-205. [CrossRef]

38. Chung, R.Y.N.; Chung, G.K.K.; Gordon, D.; Wong, S.Y.-S.; Chan, D.; Lau, M.; Tang, V.M.-Y.; Wong, H. Deprivation is associated with worse physical and mental health beyond income poverty: A population-based household survey among Chinese adults. Qual. Life Res. 2018, 27, 2127-2135. [CrossRef] [PubMed]

39. Zhang, T.; Huang, B. Local retail food environment and consumption of fruit and vegetable among adults in Hong Kong. Int. J. Environ. Res. Public Health 2018, 15, 2247. [CrossRef]

40. Baron, R.M.; Kenny, D.A. The moderator-mediator variable distinction in social psychological research: Conceptual, strategic, and statistical considerations. J. Personal. Soc. Psychol. 1986, 51, 1173-1182. [CrossRef]

41. Preacher, K.J.; Hayes, A.F. SPSS and SAS procedures for estimating indirect effects in simple mediation models. Behav. Res. Methods Instrum. Comput. 2004, 36, 717-731. [CrossRef]

42. Lu, Y.; Sarkar, C.; Xiao, Y. The effect of street-level greenery on walking behavior: Evidence from Hong Kong. Soc. Sci. Med. 2018, 208, 41-49. [CrossRef]

43. Lu, Y.; Xiao, Y.; Ye, Y. Urban density, diversity and design: Is more always better for walking? A study from Hong Kong. Prev. Med. 2017, 103, S99-S103. [CrossRef]

44. Wang, D.; Lin, T. Built environments, social environments, and activity-travel behavior: A case study of Hong Kong. J. Transp. Geogr. 2013, 31, 286-295. [CrossRef]

45. Wang, D.; Cao, X. Impacts of the built environment on activity-travel behavior: Are there differences between public and private housing residents in Hong Kong? Transp. Res. Part A Policy Pract. 2017, 103, 25-35. [CrossRef]

46. Giles-Corti, B.; Gunn, L.; Hooper, P.; Boulange, C.; Diomedi, B.Z.; Pettit, C.; Foster, S. Built Environment and Physical Activity. In Integrating Human Health into Urban and Transport Planning; Nieuwenhuijsen, M., Khreis, K., Eds.; Springer: Berlin/Heidelberg, Germany, 2019; pp. 347-381.

47. Helbich, M.; Yao, Y.; Liu, Y.; Zhang, J.; Liu, P.; Wang, R. Using deep learning to examine street view green and blue spaces and their associations with geriatric depression in Beijing, China. Environ. Int. 2019, 126, 107-117. [CrossRef] [PubMed]

48. Lu, Y. Using Google Street View to investigate the association between street greenery and physical activity. Landsc. Urban Plan. 2018, 191, 103435. [CrossRef]

49. Lu, Y.; Yang, Y.; Sun, G.; Gou, Z. Associations between overhead-view and eye-level urban greenness and cycling behaviors. Cities 2019, 88, 10-18. [CrossRef]

50. VanderWeele, T.J.; Chiba, Y. Sensitivity analysis for direct and indirect effects in the presence of exposure-induced mediatoroutcome confounders. Epidemiol. Biostat. Public Health 2014, 11, e9027.

51. Nguyen, T.Q.; Schmid, I.; Stuart, E.A. Clarifying causal mediation analysis for the applied researcher: Defining effects based on what we want to learn. Psychol. Methods 2021, 26, 255. [CrossRef] 